\title{
Role of the External Auditor in Reducing Tax Evasion (Field Study- Tax Chamber of Sudan)
}

\author{
Dr. Sherien Mamoun; Sayed Ahmed Mohamed \\ Assistant Professor in Accounting - Alfajr College for sciences and Technology
}

\begin{abstract}
The study investigated role of external auditor in reducing tax evasion. The problem of the study represented in there is fraud and fraud in tax payments. We find that the tax administration in countries face difficulties that reduce tax revenues and this affects the achievement of the desired goals. Sudan is one of the countries experiencing tax evasion. The study aimed to shed light on the previous studies that dealt with the subject of external auditor and findings to be the starting point for this research, to highlight the importance of external auditor and the role of the external auditor in reducing tax evasion. The importance of the study lies in external auditor and the role played by and contributes to the verification of detection and control tax evasion. The study adopted inductive approach, descriptive analytical approach, and historical approach. The questionnaire used to collect data from taxation chamber of Sudan. To achieve the goals of the study, the following hypotheses were tested: First hypothesis: external auditor contributes to discovering tax evasion, Second hypothesis: external auditor helps in reducing the effects of profit's volume in income statements. The study found that; the external auditor contributes to the disclosure of misleading information intended to be provided by the taxpayer, External auditor helps to detect unjustified expenses and expenses used by the taxpayer. The study recommended several recommendations, among which is that; Dependence on the audited financial statements by a legal auditor in the tax report, Encouraging companies to provide services in return for payment of tax.
\end{abstract}

Keywords:- External Auditor, Tax Evasion, Tax chamber.

\section{METHODOLOGICAL FRAMEWORK}

The importance of the accounting profession and its education is increased by increasing the practice of different economic activities, as the only means to measure the results of the business. The accounting outputs are the basis on which the decision makers depend on the conduct of their various businesses. This has increased the need for the credibility and quality of this information, to activate the external auditor profession and to apply accounting standards and to prepare sound and effective financial reports. This profession has the advantage of health and credibility and requires the imposition of control tools, and this is provided by the external auditor work, which is a greater guarantee on the credibility of these lists and this is because the external auditor enjoys independence and impartiality of opinion and show the need for external audit in light of weak internal control systems of different institutions. Taxation plays an important economic, social and political role in all developing and developed countries alike, as well as many economic, social and political goals that are implemented through taxation. However, tax administrations in all countries of the modern world are facing an obstacle that reduces the tax revenues, and thus adversely affect the achievement of the desired goals of taxation, and this is the threat of tax evasion, and Sudan is one of the countries that suffer from this phenomenon associated with them. Although the tax administration in Sudan has taken many measures to curb this phenomenon, and it is noticeable among the financiers, so it is paying increasing attention to the external audit to reduce tax evasion as one of the main access of the success of tax administration and verification of the obligation of taxpayers to implement the requirements Tax legislation.

\section{* Statement of problem:}

For resolve this problem we formulated the following questions:

Q1: Does the external auditor contribute to discovering tax evasion?

Q2: Is an external auditor helps in reducing the effects of profit's volume in income statements?

\section{* Importance of the study:}

The study concerned the assessment of the external auditor and its role in achieving the obligation to pay the tax and highlight the importance of external audit and the role played by and contribute to the verification of detection and control tax evasion.

\section{* Objectives of the study:}

The aim of this study is to achieve the following objectives:

a. To shed light on the previous studies that dealt with the subject of external audit and findings to be the starting point for this research.

b. To highlight the importance of external audit and the role of the external auditor in reducing tax evasion.

c. Knowing the importance of external auditing and its ability to contribute to the fight against tax evasion.

\section{* Hypotheses of the study:}

To achieve the study's objectives, the following hypotheses were tested: H1. External auditor contribute to discovering tax evasion.

$\mathrm{H} 2$. External auditor help in reducing the effects of profit volume in income statements. 
* Sources of data collection:

Initial Sources: The primary data of this study collected using questionnaire.

Secondary Sources: Secondary collected from references, previous studies related to research subject and internet.

\section{* Methodology of the Study:}

The study adopted inductive approach, analytical descriptive approach, and historical approach.

\section{* Limits of the study:}

a. Spatial boundaries: Khartoum state

b. Time limits: the year 2019 .

\section{PREVIOUS STUDIES REVIEW}

The study of Ali Mustafa (2020) External audit is an important factor in maximizing, collecting and increasing the efficiency of the financial departments with regards to controlling the budget revenues and making them smoother and also in the production of accurate and credible tax data and thus a real and fair taxation that achieves the objectives of different parties. External audit works on increasing and promoting the voluntary tax compliance, detecting and deterring cases of tax evasion, controlling the tax collection process almost completely, reducing the efforts of the tax departments through relying on the tax disclosure which would be provided by the taxpayer after an effective audit process; such a process contributes significantly to the prevention of intentional and unintentional cases of tax evasion resulting from fraud and error in both the tax data provided and the financial data on which data was prepared. This subject was strengthened by a field study based on a questionnaire to test the research hypotheses and reach to a set of findings and recommendations, most important of which is that the external audit has a positive role in improving tax collection through the adaptation of the financial departments on the tax disclosure prepared and approved by the auditor and ensuring the existence of a previous process in this regard that would reduce tax collection costs, contributes to the transition from a comprehensive data auditing to selective auditing and helps to eliminate past tax accumulations.

The study of Ward ,( 2014 ) The study investigated contributing external audit in improving the quality of accounting information, the problem of study represented question the extent to which external audit contributes to improving the quality of accounting information? The study also aimed at clarifying the importance and objectives of the external audit with the importance of the quality of the accounting information and the need of the users of the accounting information, clarifying the relationship between the external audit of the two accounts and the accounting information, and finding the missing link between the accounting staff and the audit work. External audit on the basis of theory, professionalism and field experience with the auditor's commitment in the preparation of reports taking into account the steps and principles in place, which ensures a good report, increased demand for external audit as a result of users of the Financial Facilities for the subject matter study. The researcher recommends institutions need to show the financial statements show the reality or the real image of the institution.

The study of Mescal, (2012), Corporate Tax Compliance: The Role of Internal and External Preparers". The study aimed to examine the tax reporting strategies to understand how companies manage this difficult task, and the impact of the tax return preparers regarding the tax status of companies and specifically whether the kind of the preparers (external or internal auditor or the chartered not auditing accountant of the company) is related to the chartered tax avoidance through creative accounting methods that legally reduce the tax burdens. By applying the questionnaires to the tax executives and with the use of the data of the U.S. Tax Dept. on those who signed the company's tax return, it was concluded that the preparers of the kind "internal auditors" and "chartered accountants-not auditors" showed a greater avoidance of taxes than the preparers of the kind "external auditors" of the company. The study also showed that only $36 \%$ of the tax executives use external resources in planning for their job and for the decisions related to taxes to which the US economy companies are committed. The study showed that using the company's external auditor for such job was rare .

The study of Al- Hussein (2008) entitled with: "the extent of dependence on the accounting information in estimating the income tax of the Palestinian companies. The study examined the extent of relying on the accounting information in estimating tax in the joint companies in the Gaza Strip. The study aimed to identify whether the joint stock company uses accounting systems and identify the qualitative characteristics of the accounting information produced by such systems. The study also aimed to find out whether the Income Tax Department examines the control methods of the accounting programs and their impact on the assessment process in addition to the impact of regulating the accounting profession on the assessment process. The study also aimed to figure out the most frequently used method of estimation by the Income Tax Dept. on the joint companies. The study concluded many results, most important of which is that the joint stock companies have good elements for the accounting system and that they use the disclosure methods very well.

\section{THEORETICAL FRAMEWORK OF EXTERNAL AUDITOR:}

\section{* Concept of External Auditor:}

Audit is a systematic and independent examination of books, accounts, statutory records, documents and vouchers of an organization to ascertain how far the financial statements as well as non-financial disclosures present a true and fair view of the concern. It also attempts to ensure that the books of accounts are properly maintained by the concern as required by law. Auditing has become such a ubiquitous phenomenon in the corporate and the public sector that academics started identifying an "Audit Society", (Michael. 1999. Oxford). The American Accounting 
Association has defined the review as a "systematic and systematic process of collecting and evaluating evidence and evidence Which relate to the results of economic activities and events, in order to determine the compatibility and congruence between these results, Established criteria, and reporting to the parties concerned on the results of the review (Abdel Majid Abdullah, 2000,). Some professors defined the audit as "the process of verifying the validity of a person's allegations and until the review is conducted efficiently, Based on logical and consistent rules and standards that define the meaning of this process and the circumstances in which it is practiced. (Qahmoush, 2013, p51).

\section{* Importance of external audit}

Companies often hire external auditors in addition to auditing themselves. External auditors are accountants who work independently of a particular company. They examine company records and operations to ensure financial statements are accurate. External auditors are important to establishing your small business' credibility and to ensuring compliance with tax laws. . (Musameh,2017 p23,)

\section{* Objective of External Audit}

\section{a. Primary objectives}

The primary objective of an auditors is to respect to the owners of his business expressing his opinion whether account exhibits true and fair view of the state of affair of the business. It should be remembered that in case of the company, he reports to the shareholders who are the owners of the company and not tot the directors. The auditors is also concerned with verifying how far the accounting system is successful in correctly recording transaction. He hat to see whether accounts are prepared in accordance with recognized accounting policies and practices and as per statuary requirement (Fazal, p27, 2013) .

\section{b. Secondary objectives :}

- Deduction and prevention of errors: errors are mistakes committed unintentionally because of ignorance, carelessness

\section{* Type of audit :}

a Financial : Financial audits typically involve a focus on financial controls as they relate to reporting. These audits focus on accounting controls present in the general ledger or sub-ledger systems. Financial statement auditing is the focus of our external auditors. Internal Audit will complement the work they perform based on an agreed plan.

b. Operational : Operational audits focus on the review and assessment of a business process. The activities of the business process may result in a direct or indirect financial impact to the organization such as the collection of student tuitions or patient account balances. Internal Audit primarily focuses on operational audits but can extend the scope to include accounting procedures that can impact financial reporting. c. Compliance : Compliance audits review the level of compliance with internal policies or external regulatory requirements. Information Systems - Audits of Information Systems look at the overall infrastructure and network of the University and the controls that relate to the security of the network and the systems that are maintained in support of the goals of the University. They also include technical operations, data center operations, project management procedures, and application controls.

d. Integrated Audits : Integrated audits look at controls that address financial, operational, compliance and information systems risks. These audits are typically centered on a business cycle or a specific part of a cycle or process.( Steven Braggp2, 2016,).

\section{THEORETICAL FRAMEWORK OF TAX}

\section{* Concept of Tax :}

The tax is a mandatory financial contribution paid by individuals on a final basis In contrast; countries are contemplating more effective ways of providing them with what they need of money without threatening its economy, so found in the collection of funds the best solution (Rube,2016,p44 )

\section{* Definitions of Tax:}

The tax is defined as "a monetary obligation that the individual owes to the performance of the State in accordance with specific rules A member of society not only for the purpose of spending for the common good but also for the welfare of all the people. (Al-Mahayni, 2011,p55).

* Importance of Tax :

a. Tax is a major source of government revenue and its contributes for the overall development and prosperity of a country. Raising government revenue in terms of income tax, custom duty, excise duty, entertainment tax, VAT, land revenue tax etc. from various sectors in order to initiate development and welfare programmers.

b. Reducing regional economic disparity by encouraging the entrepreneurs to establish industries in remote and backward regions by giving tax exemptions, rebates and concessions etc.( Bhīma, 2002, p45 ).

* Type of taxes:

a. Direct taxes :

- Income Tax- It is imposed on an individual who falls under the different tax brackets based on their earning or revenue and they have to file an income tax return every year after which they will either need to pay the tax or be eligible for a tax refund.

- Estate Tax-Also known as Inheritance tax, it is raised on an estate or the total value of money and property that an individual has left behind after their death.

- Wealth Tax- Wealth tax is imposed on the value of the property that a person possesses.

- Corporation Tax Corporation Tax is paid by Companies and Businesses operating in India on the income earned worldwide in a given financial year. The rates of taxation 
vary based on whether the company is incorporated in India or abroad.

- Capital Gains Tax The profits made on sale of property are taxable under Capital Gains Tax. Property here includes stocks, bonds, residential property, precious metals etc. It is taxed at two different rates based on how long the property was owned by the taxpayer - Short Term Capital Gains Tax and Long Term Capital Gains Tax. This deciding period of ownership varies greatly for different classes of property.( Abdul,2012,p37) .

\section{b. In direct taxes :}

- Customs Duty- It is an Import duty levied on goods coming from outside the country, ultimately paid for by consumers and retailers in India.

- Central Excise Duty- This tax was payable by the manufacturers who would then shift the tax burden to retailers and wholesalers.

- Service Tax- It was imposed on the gross or aggregate amount charged by the service provider on the recipient.

- Sales Tax- This tax was paid by the retailer, who would then, shifts the tax burden to customers by charging sales tax on goods and service.

- Value Added Tax (VAT) - It was collected on the value of goods or services that were added at each stage of their manufacture or distribution and then finally passed on to the customer. (cleartax.in/s/direct-indirect-taxationIndirect -explained 2018).

\section{THEORETICAL FRAMEWORK OF TAX EVASION :}

\section{* Concept of Tax Evasion}

Is the non-payment of tax payable by the taxpayer, which is either part of it or all the percentage imposed on it, and evasion before or during the payment period using certain illegal means. ( Dhaka. p14 ,2007).

\section{* Definitions of Tax evasion}

Tax evasion is a general term that refers to the efforts of individuals or institutions to evade taxation by legal means. Tax evasion usually involves defamation or deliberate concealment of the taxpayer's real status vis-a-vis the tax authorities to reduce the value of taxes, including in particular the submission of in accurate tax reports, For profits less than its real value. ( Michael Wenzel (2002). Tax evasion is intended to eliminate the taxpayer from the performance of the tax, as a result of benefiting from some gaps in the tax legislation, which result in the disposal of the payment of the tax without there being a violation of legal texts, and known as the evasion legitimate .( Farad, p3,2001)

\section{* Effects of tax evasion :}

The effects of tax evasion can be limited to two main groups: economic and financial, on the one hand, and social and political impacts on the other.

a. The financial and economic implications of tax evasion: All countries of the world, regardless of their political doctrines and economic systems, rely on taxes mainly to achieve their objectives. So tax evasion will prevent taxes from achieving those goals.

b. On the financial level, tax evasion causes substantial damage to the state treasury, by losing an important part of the proceeds, which would not have been lost without such evasion. (Qahmoush,2013. P56) Qahmoush.

\section{FIELD STUDY}

\section{* Field study procedures:}

The researchers discuss the method and procedures followed in the implementation of the study. This includes a description of the study community, the sample of the study, the method of preparing its tools, and the statistical methods used to test the hypothesis of the study. The study community is the total group of elements that the researcher seeks to generalize the results related to the problem. The study community consists of Tax chamber of Sudan.

The study's sample: The sample of the study was determined according to its scientific specifications that achieve the objectives of the study from the internal auditor, external auditor, accountant, risk office, investment officer, and head of department, to achieve the purpose of the study.

Data collection: A total of (011) forms were distributed on the pre-defined and targeted sample to verify the hypotheses of the study. A total of (01) forms were collected for analysis, (01\%), To produce accurate results and disseminate them to the study community, the researchers are keen to vary the sample of the study in terms of its coverage on the following:

a. Individuals of different years of age (less than 30 years, 30 years and less than 35 years, 35 years and less than 40 years, more than 40 years).

b. Individuals with different qualifications (BSc, High Diploma, Master, PhD, Other).

c. Individuals from different scientific disciplines (accounting, financial and banking studies, business administration, accounting information systems, economics, other.).

d. Individuals of various functional occupations (internal auditor, external auditor, accountant, risk office, investment officer, department head, other).

e. Individuals of different years of experience (less than 5 years, 5 years and less than 10 years, 10 years and less than 15 years, 15 years and less than 20 years, more than 20 years).

Tools of the study: The tools of the study are the means used by the researcher to collect the necessary data on the phenomenon studied. There are many tools used in the field of scientific research to obtain the necessary information and data. The researcher adopted the questionnaire as a main tool for collecting data from the study sample:

a. Applicable for information from a number of individuals.

b. Low cost and easy to apply.

c. Easy to develop questions and answer questions and answer questions. d. The questionnaire provides time for the respondent and gives him an opportunity to think.

d. Respondents in the questionnaire feel free to express opinions they fear others disagree with. 


\section{- Stability and truthfulness Study tools:}

a. Stability and Virtual Honesty:

In order to ascertain the veracity of the questionnaires, the researchers presented the questionnaire to a number of academic arbitrators and specialists in the field of study. After the questionnaire was retrieved from the arbitrators, the proposed amendments were made. Stability and statistical honesty: The consistency of the test means that the scale gives the same results if used once under similar conditions. Stability means that if a test is applied to a group of individuals and their scores are monitored, then the same test is applied to the same group and the scores are obtained, the test is perfectly stable, also known as the accuracy and consistency of the measurements obtained from the test. The most commonly used methods for estimating the stability of a scale are (Half-way distribution using the Spearman-
Brown formula, Alpha-Cronbach method, Method of reapplication of the test).Honesty is a measure used to determine the degree of honesty among respondents through their answers to a given scale.

\section{b. Use a questionnaire for survey sample:}

The questionnaire was distributed to a sample of (5) individuals from the research community and from outside the research sample in accordance with their characteristics with the sample of the study to calculate the stability factor, to determine the degree of response of the respondents to the questionnaire and to identify ambiguous questions and to provide preliminary testing of hypotheses and to clarify some design and methodological problems. The stability test for the questionnaire was conducted using the alphaCronbach coefficient and the result was 0.873 . This means that the data is stable as shown in Table (1) below:

\begin{tabular}{|c|c|c|c|}
\hline Number & Axis & Number of ferries & Stability(constancy) \\
\hline 1 & first hypothesis & 5 & 0.269 \\
\hline 2 & second hypothesis & 5 & 1.276 \\
\hline & Total & 10 & 0.977 \\
\hline
\end{tabular}

Table (1):- Alpha Cronbach Coefficient of the Questionnaire

Source: Researcher, 2020.

The above table shows that the Kronbach coefficient for all the terms of the questionnaire is 0.977 which is high and the reference to the terms of the questionnaire is that the increase in the value of the Cronbach coefficient means increasing the credibility of the data. This means that the measure measures what is measured.

Used Statistical methods: To achieve the objectives of the study and to verify its hypotheses, the statistical methods used are (Frequency distribution of responses, Percentages, Spearman-Brown equation to calculate the coefficient of stability, Arithmetic mean, standard deviation and variance and chi - square test to denote hypotheses).

\section{* Data analysis and hypothesis testing}

The researchers analyzed personal data, questionnaire data and tested the hypotheses of the study using statistical methods. In addition, a comparison is made between the most important results of the field study and the results of the previous studies, as follows:

* Analysis of the questionnaire data:

First hypothesis: External auditor contribute to discovering tax evasion .

\begin{tabular}{|c|c|c|c|c|c|c|c|c|c|c|c|}
\hline \multirow[t]{3}{*}{ No } & \multirow[t]{3}{*}{ Sentences } & \multicolumn{10}{|c|}{ Frequency and percentage $\%$} \\
\hline & & \multicolumn{2}{|c|}{$\begin{array}{l}\text { Strongly } \\
\text { Disagree }\end{array}$} & \multicolumn{2}{|c|}{ disagree } & \multicolumn{2}{|c|}{ Neutral } & \multicolumn{2}{|c|}{ Agree } & \multicolumn{2}{|c|}{$\begin{array}{l}\text { Strongly } \\
\text { agree }\end{array}$} \\
\hline & & $F$ & $P$ & $\mathrm{f}$ & $\mathrm{p}$ & $\mathrm{f}$ & $P$ & $F$ & $P$ & $\mathrm{f}$ & $P$ \\
\hline 1 & $\begin{array}{l}\text { The external auditor contributes to the disclosure of } \\
\text { misleading information intended to be provided by the } \\
\text { taxpayer. }\end{array}$ & 1 & $\begin{array}{c}3.3 \\
\%\end{array}$ & 0 & $0 \%$ & 0 & $0 \%$ & 1 & $\begin{array}{c}3.3 \\
\%\end{array}$ & 28 & $\begin{array}{c}93.3 \\
\%\end{array}$ \\
\hline 2 & $\begin{array}{l}\text { The external auditor contributes to the disclosure of the } \\
\text { existence of fraudulent papers and import invoices. }\end{array}$ & 1 & $\begin{array}{l}3.3 \\
\%\end{array}$ & 0 & $0 \%$ & 0 & $0 \%$ & 4 & $\begin{array}{c}13.3 \\
\%\end{array}$ & 25 & $\begin{array}{c}83.3 \\
\%\end{array}$ \\
\hline 3 & $\begin{array}{l}\text { The external auditor contributes to the disclosure of the } \\
\text { existence of fraudulent papers and import invoices. }\end{array}$ & 1 & $3.3 \%$ & 0 & $0 \%$ & 0 & $0 \%$ & 1 & $3.3 \%$ & 28 & $93.3 \%$ \\
\hline 4 & $\begin{array}{l}\text { The external auditor contributes to the detection of the non- } \\
\text { payment of income tax for institutional workers. }\end{array}$ & 1 & $\begin{array}{c}3.3 \\
\%\end{array}$ & 0 & $0 \%$ & 0 & $0 \%$ & 0 & $0 \%$ & 29 & $\begin{array}{c}96.7 \\
\%\end{array}$ \\
\hline
\end{tabular}

Table (2):- The frequency distribution of the responses of the sample members of the study for the first hypothesis phrases Source: Prepared by researcher, based on field study's data, 2020 
From table (2) that explains the ratios and frequencies of the hypothesis expressions, which states, "External auditor contribute to discovering tax evasion.", the researcher noticed that, the respondents, answers are strongly agree and agree.

\begin{tabular}{|c|c|c|c|c|}
\hline No & Sentences & Mean & Mode & Explanation \\
\hline 1 & $\begin{array}{c}\text { The external auditor contributes to the disclosure of misleading } \\
\text { information intended to be provided by the taxpayer. }\end{array}$ & 4.76 & 5 & Strongly agree \\
\hline 2 & $\begin{array}{c}\text { The external auditor contributes to the disclosure of the existence } \\
\text { of fraudulent papers and import invoices. }\end{array}$ & 4.73 & 5 & Strongly agree \\
\hline 3 & $\begin{array}{c}\text { The external auditor contributes to the disclosure of the existence } \\
\text { of fraudulent papers and import invoices. }\end{array}$ & 4.80 & 5 & Strongly agree \\
\hline 4 & $\begin{array}{c}\text { The external auditor contributes to the detection of the non- } \\
\text { payment of income tax for institutional workers. }\end{array}$ & 4.86 & 5 & Strongly agree \\
\hline 5 & $\begin{array}{c}\text { External auditor helps to detect non-registration with income and } \\
\text { sales tax. }\end{array}$ & 4.83 & 5 & \\
\hline
\end{tabular}

Table (3):- The mean and the mode of the responses of the sample members of the study for the phrases of the first hypothesis Source: Prepared by researcher, based on field study's data, 2020

From table (3), the researcher noticing that the descriptive statistics of the first hypothesis's terms which states, "External auditor contribute to discovering tax evasion, the arithmetic mean is in the range between $(4.73-4.86)$ and the mode is in the range between (4-5). According to the Five-digit Liker's scale, the respondents, answers are; strongly agree and agree.

\begin{tabular}{|c|c|c|c|c|}
\hline No & Sentences & Chi-square & $\begin{array}{l}\text { Degree of } \\
\text { freedom }\end{array}$ & $\begin{array}{l}\text { Statistical } \\
\text { significance }\end{array}$ \\
\hline 1 & $\begin{array}{l}\text { The external auditor contributes to the disclosure of misleading } \\
\text { information intended to be provided by the taxpayer. }\end{array}$ & 64.310 & 1 & .000 \\
\hline 2 & $\begin{array}{l}\text { The external auditor contributes to the disclosure of the } \\
\text { existence of fraudulent papers and import invoices. }\end{array}$ & 59.186 & 2 & .000 \\
\hline 3 & $\begin{array}{l}\text { The external auditor contributes to the disclosure of the } \\
\text { existence of fraudulent papers and import invoices. }\end{array}$ & 50.866 & 2 & .000 \\
\hline 4 & $\begin{array}{l}\text { The external auditor contributes to the detection of the non- } \\
\text { payment of income tax for institutional workers. }\end{array}$ & 40.351 & 1 & .000 \\
\hline 5 & $\begin{array}{l}\text { External auditor helps to detect non-registration with income } \\
\text { and sales tax. }\end{array}$ & 53.264 & 2 & .000 \\
\hline
\end{tabular}

Table (4):- Test of Chi - square for the first hypothesis

Source: Prepared by researcher, based on field study's data, 2020.

In order to test the validity of the hypothesis, which states, "External auditor contribute to discovering tax evasion. the chisquare test used for the axis expressions. The values of the chi- square calculated as $(64.310,59.186,50.866,40.351,53.264)$, with degrees of freedom (1-2). And with the statistical significance for all terms (0.00), When comparing the level of statistical significance with the permissible level of significance (0.05), we find that the level of statistical significance is less than the level of morale, which means of terms hypothesis. From above discussion, the researcher conclude that, the first hypothesis that states, "External auditor contribute to discovering tax evasion.

The second hypothesis: "External auditor help in reducing the effects of profit volume in income statements." 


\begin{tabular}{|c|c|c|c|c|c|c|c|c|c|c|c|}
\hline \multirow[t]{3}{*}{ No } & \multirow[t]{3}{*}{ Sentences } & \multicolumn{10}{|c|}{ Frequency and percentage $\%$} \\
\hline & & \multicolumn{2}{|c|}{$\begin{array}{l}\text { Strongly } \\
\text { Disagree }\end{array}$} & \multicolumn{2}{|c|}{ disagree $\mathrm{e}$} & \multicolumn{2}{|c|}{ Neutral } & \multicolumn{2}{|c|}{ Agree } & \multicolumn{2}{|c|}{ Strongly agree } \\
\hline & & $\mathrm{F}$ & $\mathrm{P} \%$ & $\mathrm{f}$ & $\mathrm{p}$ & $\mathrm{F}$ & $\mathrm{P}$ & $\mathrm{f}$ & $\mathrm{P}$ & $\mathrm{F}$ & $\mathrm{P}$ \\
\hline 1 & $\begin{array}{l}\text { External auditor helps to detect unjustified expenses } \\
\text { and expenses used by the taxpayer. }\end{array}$ & 1 & $\begin{array}{c}3.3 \\
\%\end{array}$ & 0 & $\begin{array}{l}0 \\
\%\end{array}$ & 1 & $\begin{array}{c}3.3 \\
\%\end{array}$ & 1 & $\begin{array}{c}3.3 \\
\%\end{array}$ & 27 & $\begin{array}{l}90 \\
\%\end{array}$ \\
\hline 2 & $\begin{array}{l}\text { The external auditor contributes to the disclosure of } \\
\text { the importation of goods without authorization. }\end{array}$ & 1 & $\begin{array}{l}3.3 \\
\%\end{array}$ & 0 & $\begin{array}{l}0 \\
\%\end{array}$ & 1 & $\begin{array}{c}3.3 \\
\%\end{array}$ & 7 & $\begin{array}{c}23.3 \\
\%\end{array}$ & 21 & $\begin{array}{l}70 \\
\%\end{array}$ \\
\hline 3 & $\begin{array}{l}\text { External auditor helps to detect the use of virtual } \\
\text { users in organizations. }\end{array}$ & 1 & $\begin{array}{l}3.3 \\
\%\end{array}$ & 0 & $\begin{array}{l}0 \\
\%\end{array}$ & 1 & $\begin{array}{c}3.3 \\
\%\end{array}$ & 2 & $\begin{array}{c}6.7 \\
\%\end{array}$ & 26 & $\begin{array}{c}86.7 \\
\%\end{array}$ \\
\hline 4 & $\begin{array}{l}\text { External auditor contributes to the disclosure of sales } \\
\text { reductions. }\end{array}$ & 1 & $\begin{array}{c}3.3 \\
\%\end{array}$ & 0 & $\begin{array}{l}0 \\
\%\end{array}$ & 1 & $\begin{array}{c}3.3 \\
\%\end{array}$ & 3 & $\begin{array}{l}10 \\
\%\end{array}$ & 25 & $\begin{array}{c}83.3 \\
\%\end{array}$ \\
\hline 5 & $\begin{array}{l}\text { External auditor helps to uncover documents that } \\
\text { reduce income. }\end{array}$ & 1 & $\begin{array}{l}3.3 \\
\%\end{array}$ & 0 & $\begin{array}{l}0 \\
\%\end{array}$ & 1 & $\begin{array}{c}3.3 \\
\%\end{array}$ & 1 & $\begin{array}{l}3.3 \\
\%\end{array}$ & 27 & $\begin{array}{l}90 \\
\%\end{array}$ \\
\hline
\end{tabular}

Table (5):- The frequency distribution of the responses of the sample members of the study for the second hypothesis phrases Source: Prepared by researcher, based on field study's data, 2020.

From table (5), which explains the ratios and frequencies of the hypothesis terms, which states, "External auditor help in reducing the effects of profit volume in income statements." the researcher noticed that, the respondents, answers are strongly agree and agree.

\begin{tabular}{|c|c|c|c|c|}
\hline No & Sentences & Mean & mode & Explanation \\
\hline 1 & $\begin{array}{c}\text { External auditor helps to detect unjustified expenses and expenses used by } \\
\text { the taxpayer. }\end{array}$ & 4.76 & 5 & Strongly agree \\
\hline 2 & $\begin{array}{c}\text { The external auditor contributes to the disclosure of the importation of goods } \\
\text { without authorization. }\end{array}$ & 4.56 & 5 & Strongly agree \\
\hline 3 & External auditor helps to detect the use of virtual users in organizations. & 4.73 & 5 & Strongly Agree \\
\hline 4 & $\begin{array}{c}\text { External auditor contributes to the disclosure } \\
\text { of sales reductions. }\end{array}$ & 4.70 & 5 & Strongly agree \\
\hline 5 & External auditor helps to uncover documents that reduce income. & 4.77 & 5 & Strongly agree \\
\hline
\end{tabular}

Table (6):- The mean and the mode of the responses of the sample members of the study for the phrases of second hypothesis Source: Prepared by researcher, based on field study's data, 2020

From table (6), the researcher noticed from the descriptive statistics of the first hypothesis's terms, which states, "External auditor help in reducing the effects of profit volume in income statements.", the Arithmetic mean is in the range (4.56 - 4.77), and the mode is in the range between (2-5). According to the five-digit Likert's scale, the respondents' answers are; strongly agree and agree.

\begin{tabular}{|c|c|c|c|c|}
\hline No & Sentences & Chi-square & Degree of freedom & Statistical significance \\
\hline 1 & $\begin{array}{c}\text { External auditor helps to detect unjustified expenses } \\
\text { and expenses used by the taxpayer. }\end{array}$ & 51.786 & 1 & .000 \\
\hline 2 & $\begin{array}{c}\text { The external auditor contributes to the disclosure of the } \\
\text { importation of goods without authorization. }\end{array}$ & 32.374 & 2 & .000 \\
\hline 3 & $\begin{array}{c}\text { External auditor helps to detect the use of virtual users } \\
\text { in organizations. }\end{array}$ & 31.635 & 1 & .000 \\
\hline 4 & $\begin{array}{c}\text { External auditor contributes to the disclosure of sales } \\
\text { reductions. }\end{array}$ & 63.828 & 2 & .000 \\
\hline 5 & External auditor helps to uncover documents that \\
reduce income. & 63.159 & & .000 \\
\hline
\end{tabular}

Table (7):- Test of Chi - square for the second hypothesis

Source: Prepared by researcher, based on field study's data, 2020. 
In order to test the validity of the hypothesis, which states, "External auditor help in reducing the effects of profit volume in income statements..", the Chi-square test used for the axis expressions. The values of the Chi-square calculated as $(51.786,32.374,31.635,63.828,63.159)$, with degrees of freedom (1-2), and with the statistical significance for all terms (0.00).

When comparing the level of statistical significance with the permissible level of significance $(0.05)$ we find that the level of statistical significance is less than the level of morale, which means of terms hypothesis. From above discussion, the researcher conclude that, the second hypothesis that states, "External auditor help in reducing the effects of profit volume in income statements." achieved .

\section{CONCLUSIONS AND RECOMMENDATIONS}

\section{* First : Conclusions}

After completing the theoretical framework of the study and data, researcher found the following results:

a. The external audit contributes to the disclosure of the existence of fraudulent papers and import invoices.

b. The external audit contributes to the detection of the non-payment of income tax for institutional workers.

c. The external audit contributes to the disclosure of misleading information intended to be provided by the taxpayer.

d. External auditing helps to uncover documents that reduce income.

e. External audit helps to detect unjustified expenses and expenses used by the taxpayer.

f. External audit helps to detect the use of virtual users in organizations

\section{* Second: Recommendations :}

Base on the results of this study, researcher recommended the following:

a. External audit helps to detect the use of virtual users in organizations

b. The need to encourage savings.

c. Encouraging companies to provide services in return for payment of tax.

d. Activation of strict laws and procedures to reduce tax evasion.

e. The need to activate the auditor's job with regards to the adoption of the tax statement and forcing the income estimators to accept the figures contained therein without any increase in most cases.

\section{REFERENCES}

[1]. Ali Mustafa Magablih, Role of the External Auditor in Maximizing Budget Revenues Jordan as a Case Study , Journal of Public Administration and Governance ISSN 2161-7104 2020, Vol. 10, No. 1,pp 182.

[2]. Nasser Mahmoud Madani. ,Tax evasion and impact on the national economy, a message Master of Economic Development and Strategic Planning, Mansoura University, Khartoum, 2014,pp45.

[3]. Kenneth, K. P., Lisowsky, D., \& Mescall, (2012). University Avenue, West Waterloo, Corporate Tax Compliance: The Role of Internal and External Preparers, Canada, 2012. https://doi.org/10.2139/ssrn.2152538 .

[4]. Al-Husseini, H. (2011). Accounting Responsibility. journal of Baghdad Faculty of Economics, 2008 .

[5]. Michael. 1999. The Audit Society: Rituals of Verification. Oxford: Oxford University Press .

[6]. Abdul Majid Abdullah Ahmed (2002), Principles of Auditing (Omdurman: Dar Omdurman Islamic University.

[7]. Abdul, G. H. (2012). The relationship between the taxpayer and the tax administration and its impact on collection and taxation, (Master's Thesis), Al-Najah National University, Palestine, 2012.

[8]. Musameh, M., \& Laqwera, S. (2017). the contribution of the vocational specialization of the External Auditor in improving the quality of the Audit: field study on a sample of external auditors in the state of Biskra. Journal of Economics, 2017.

[9]. Qahmoush, S. (2013). The role of the tax accounting in improving the quality of tax data, (Master's Thesis), University of Qasdi, 2013.

[10]. Rube, S. S. A. A. (2016). determinants of the profession market of external audit in Jordan and its impact on the quality of financial reports, Middle East University, 2016.

[11]. Al-Mahayni, K., Al-Khatib, K., \& Al-Aday. (2011). Tax Accounting. Syria: Damascus University Publications, 2011.

[12]. Abdul, G. H. (2012). The relationship between the taxpayer and the tax administration and its impact on collection and taxation, (Master's Thesis), Al-Najah National University, Palestine, 2012. 